\title{
A Theory of Hypothetical Contract
}

Legal theorists have struggled to find general principles to explain the common law of restitution for unsolicited benefits. ${ }^{1}$ This Note proposes a theory of hypothetical contract to govern such cases. A hypothetical contract is one that a court writes for the parties because it is convinced that both parties would have agreed to its terms at the time the unsolicited benefit was conferred. ${ }^{2}$ The Note argues that a court should impose a hypothetical contract if two conditions are met: 1) high transaction costs precluded an express contract; ${ }^{3}$ and 2) imposing a hypothetical contract

1. See, e.g., Restatement of Restitution, QuAsi-Contracts and Constructive Trusts $\S 1$ (1937) [hereinafter cited as RESTATEMENT of REstrTution] (beneficiary is liable if unjustly enriched); Restatement (Second) of Restrutution § 1 (Tent. Draft No. 1, 1983) (same); Landes \& Posner, Salvors, Finders, Good Samaritans, and Other Rescuers: An Economic Study of Law and Altruism, 7 J. Legal STud. 83 (1978) (efficiency considerations may explain common law rules denying recovery for most "rescues" of life or property); Wade, Restitution for Benefits Conferred Without Request, 19 VAND. L. REv. 1183, 1212 (1966) ("One who, without intent to act gratuitously, confers a measurable benefit upon another, is entitled to restitution, if he affords the other an opportunity to decline the benefit or else has a reasonable excuse for failing to do so."); see also R. POSNER, ECONOMIC ANALYSIS OF LAw 97-98, 131-34, 188-89 (2d ed. 1977) (summarizing Landes \& Posner, supra). But cf. 1 A. Corbin, Corbin on Contracts $\S 19$, at 49 (1963) (Quasi-contract includes "numerous odds and ends of obligation ... even though they have little in common with consensual agreement and ... great differences among themselves.").

2. This Note does not consider cases in which the beneficiary subsequently promises to pay for the benefit. Courts have enforced such promises under the doctrine of moral consideration. See Webb v. McGowin, 27 Ala. App. 82, 168 So. 196 (1935) (subsequent promise to pay for life rescue enforceable against decedent's estate). But see Harrington v. Taylor, 225 N.C. 690, 36 S.E.2d 227 (1945) (subsequent promise to pay plaintiff for preventing defendant's wife from killing defendant unenforceable). See generally Henderson, Promises Grounded in the Past: The Idea of Unjust Enrichment and the Law of Contract, 57 VA. L. REv. 1115 (1971) (favoring liability based on subsequent promises). Since the subsequent promise is persuasive evidence that the defendant was willing to pay for the benefit, no theory of hypothetical consent is required to impose liability.

3. Contracts are traditionally classified as express, implied-in-fact, or implied-in-law. See J. Calamari \& J. Perillo, The Law of Contracts \$1-12, at 19-20 (2d ed. 1977). The contract is express if the agreement is manifested by written or spoken words, and implied-in-fact if the agreement is manifested by other conduct. See Erickson v. Goodell Oil Co., 384 Mich. 207, 212, 180 N.W.2d 798, 800 (1970). "Contract implied in law" is a somewhat disfavored synonym for "quasicontract." See $1 \mathrm{~A}$. ConbiN, supra note $1, \S 19$, at 44 . The authorities agree that a quasi-contract is not a contract at all, since there is no actual manifestation of assent. See, e.g., Bradkin v. Leverton, 26 N.Y.2d 192, 196-97, 257 N.E.2d 643, 645, 309 N.Y.S.2d 192, 195-96 (1970) (quasi-contracts not contracts at all); $1 \mathrm{~S}$. Williston, A TREATISE on the LAW of Contracts $\S 3 \mathrm{~A}$, at 13 (3d ed. 1957) (only requirement is that quasi-contract more nearly resemble contract than tort). The common law of quasi-contract is supposed to have developed for procedural reasons. After Slade's Case, 76 Eng. Rep. 1074 (1602) (no subsequent promise necessary for action of assumpsit to lie), it was convenient to allow plaintiffs to use a writ of assumpsit and plead a fictitious promise in some cases in which no promise at all had been given. See Ames, The History of Assumpsit (pt. 2), 2 Harv. L. REv. 53, 63-69 (1888).

Hypothetical contract is not synonymous with quasi-contract, since courts frequently impose quasicontractual liability without considering the actual or hypothetical intentions of the parties. See Schott v. Westinghouse Elec. Corp., 436 Pa. 279, 290-91, 259 A.2d 443, 449 (1969) (quasi-contractual liability not based on apparent intentions of the parties); $1 \mathrm{~A}$. CoRBIN, supra note $1, \S 19$, at 46 (quasi-contractual liability imposed in spite of strong disagreement of the parties); Wade, supra note 1, at 1185 (unjust enrichment principle non-consensual). 
results in a Pareto-superior transaction.

This hypothetical contract theory explains some patterns of common law rules better than three competing analyses: the restitutive ${ }^{6}$ principle of unjust enrichment, ${ }^{\circ}$ Richard Posner's wealth-maximization principle, ${ }^{7}$ and Richard Epstein's theory of strict liability in tort. ${ }^{8} \mathrm{~A}$ contract-based approach, moreover, protects autonomy values ${ }^{\theta}$ better than any of the alternative approaches.

Part I argues that the unjust enrichment principle judges invoke in unsolicited benefit cases requires supplementation. Part II proposes and defends a theory of hypothetical contract. Part III applies the hypothetical contract theory to the common law of restitution for unsolicited benefits. ${ }^{10}$

\section{The Need for a Hypothetical Contract Theory}

Common law courts have decided a wide variety of unsolicited benefit cases. The results of these cases cannot be explained by the unjust enrichment principle alone, since that principle is too general to provide guidance in specific cases. Supplementing the unjust enrichment principle with a hypothetical contract theory explains many prior decisions and provides guidance for future cases.

4. State A is Pareto-superior to State B if some individuals are better off in State A than in State $B$, and no individuals are worse off. For a general discussion of the concept of Pareto superiority, see A. Sen, Collective Choice and Social. Welfare 21-27 (1970); see also Coleman, Efficiency, Exchange, and Auction: Philosophic Aspect of the Economic Approach to Law, 68 CALIF. L. REv. 221, 226-31 (1980) (non-technical discussion of Paretian concepts). See infra p. 422 (discussing application of Pareto-superiority concept to hypothetical contracts).

5. "Restitution" is a broader term than "quasi-contract." Quasi-contract properly refers only to actions at law for damages. Restitution also includes equitable remedies such as subrogation, constructive trusts, and equitable liens. E. FARnsworth, ConTracts $\$ 2.20$, at 99 (1982).

6. The unjust enrichment principle states that "A person who receives a benefit by reason of an infringement of another person's interest, or of loss suffered by the other, owes restitution to him in the manner and amount necessary to prevent unjust enrichment." RESTATEMENT (SECOND) OF RESTrTUTION, supra note 1, §1. See generally J. DAwson, UnJust ENRICHMENT (1951) (discussion, based on civil law cases, of principle that no one should be made richer through another's loss).

7. See infra p. 423.

8. See infra p. 433.

9. Roughly, an individual's autonomy is violated when she is treated as the involuntary instrument of another's happiness. Rights may be viewed as individual boundaries which limit such violations. See R. Nozick, ANarchy, State, and Utopia 57-87 (1974); Kronman, Wealth Maximization as a Nornative Principle, 9 J. Legal. Stud. 227, 233 (1980).

10. The hypothetical contract idea does not apply only to the law of restitution. The notion has been used to explain aspects of bankruptcy law. See Jaclson, Bankruptcy, Non-Bankruptcy Entillements, and the Creditors" Bargain, 91 YALE L.J. 857 (1982) (hypothetical "creditors' bargain"). Hypothetical contract has also been applied to the attorney-client relationship in some class action suits. Dawson, Lawyers and Involuntary Clients: Allomey Fees From Funds, 87 HaRv. L. Rev. 1597 (1974) (hypothetical contracts to vindicate the public interest); Dawson, Lawyers and Involuntary Clients in Public Interest Litigation, 88 Harv. L. REv. 849 (1975) (hypothetical contracts to prosecute class actions). 


\section{A. Inadequacy of the Unjust Enrichment Principle}

The common law has been hostile to claims based on unsolicited benefits. ${ }^{11}$ Courts have allowed recovery to unsolicited intervenors in relatively few situations: providing necessities to children, ${ }^{12}$ burying the dead; ${ }^{13}$ paying another's debts in certain circumstances, ${ }^{14}$ attempts by physicians to save lives, ${ }^{16}$ saving property, in some cases; ${ }^{18}$ and conferring a benefit by mistake. ${ }^{17}$ Those who intervene in the affairs of others are often branded as "officious intermeddlers" and denied any recovery. ${ }^{18}$ Intermeddlers

11. "No person may be made a debtor against his will" is a common law slogan. See Boston Ice Co. v. Potter, 123 Mass. 28, 30 (1877); Falcke v. Scottish Imperial Ins. Co. [1886] 34 Ch. D. 234, 248 (Bowen, L.J.) ("Liabilities are not to be forced upon people behind their backs any more than you can confer a benefit upon a man against his will.").

12. See Porter v. Powell, 79 Iowa 151, 159, 44 N.W. 295, 298 (1890) (inferring from legal duty to support children a promise by parent to pay for necessities furnished to child); Van Valkinburgh v. Watson, 13 Johns. 480 (N.Y. Sup. Ct. 1816) (third party supplying necessities to child when parent neglected to do so entitled to charge parent). See also McFerren v. Goldsmith-Stern Co., $137 \mathrm{Md}$. $573,113 \mathrm{~A} .107$ (1921) (wife is authorized to pledge husband's credit to obtain necessities where husband fails to fulfill legal obligation to support wife); REsTatement of RestrTution, supra note $1, \S 113$ (One who performs another's non-contractual duty to supply necessities to third person is entitled to restitution.).

13. See Cape Girardeau Bell Tel. Co. v. Hamil, 160 Mo. App. 521, 140 S.W. 951 (1911) (employer may recover funeral expenses of employee who died at work when arrangements were made with knowledge of relatives); Rogers v. Price, 148 Eng. Rep. 1080 (1829) (legal duty of executor to bury deceased gives rise to an implied promise by executor to pay for funeral furnished by third person).

14. See Allyn v. Dreher, 124 Neb. 342, 246 N.W. 731 (1933) (holder of a subordinate mortgage who pays interest payments on superior mortgage to protect his own subordinate lien may be equitably entitled to subrogation). The cases are discussed in Dawson, The Self-Serving Interneddler, 87 HARv. L. REv. 1409, 1437-43 (1974). The general rule, however, is that there is no recovery for unsolicited payment of the debt of another. See Kelley v. Lindsey, 73 Mass. (7 Gray) 287, 290 (1856). Commentators have criticized this general rule, arguing that, since debts are usually freely assignable, courts should grant recovery. See Wade, supra note 1, at 1206-08. This argument ignores the possibilities that the original creditor may be more likely than his successor to forgive the debt, or that the original creditor may herself owe the debtor money.

15. See Cotnam v. Wisdom, 83 Ark. 601, 104 S.W. 164 (1907) (surgeon operating on unconscious accident victim allowed compensation); Matheson v. Smiley, [1932] 2 D.L.R. 787 (Man. Ct. App.) (surgeon entitled to payment even though defendant was unable to give consent). Recovery is permitted only where the service was rendered with intent to charge under circumstances which prevented the plaintiff from obtaining the defendant's consent. $C f$. Soldiers Memorial Hospital v. Sanford, [1934] 2 D.L.R. 334 (N.S.S.C.) (recovery denied where plaintiff taken to hospital against his will).

16. E.g., Chase v. Corcoran, 106 Mass. 286 (1871) (owner liable to one who saves and repairs lost boat); Berry v. Barbour, 279 P.2d 335 (Okla. 1954) (plaintiff, already under contract to repair defendant's building, who repairs roof damage after fire, entitled to reimbursement). Most cases, however, deny restitution. E.g., Bartholomew v. Jackson, 20 Johns. 28 (N.Y. Sup. Ct. 1822) (denying recovery to plaintiff who saves defendant's wheat stack from fire); Glenn v. Savage, 14 Or. 567, 577-78, 13 P. 442, 448 (1887) (denying recovery to plaintiff who saves lumber that falls into river).

17. See Sykes v. Sykes, 262 Ala. 277,78 So. $2 d 273$ (1954) (plaintiff who has paid to improve real property in erroneous belief that she was equitable owner is entitled to a lien on the property for the amount expended). But see Federal Land Bank v. Dorman, 112 Ind. App. 111, 41 N.E.2d 661 (1942) (denying recovery to one who mistakenly paid taxes due on real property).

18. See Hope, Officiousness (pts. 1 \& 2), 15 CoRnell L.Q. 25, 205, 242 (1929, 1930) (courts will grant restitution for intervention in another's affairs only when a special public interest is at stake or the intervenor acts to protect himself). 
themselves may be held civilly ${ }^{19}$ or even criminally ${ }^{20}$ liable. These antiinterventionist rules differ markedly from those of the civil law, which often permit recovery of expenses incurred in conferring unsolicited benefits, ${ }^{21}$ and from the rules of admiralty, which allow salvors to recover part of the value of salved property. ${ }^{22}$

Judges purport to decide unsolicited benefit cases by applying the restitutionary principle of unjust enrichment. ${ }^{23}$ Merely invoking "unjust enrichment," however, begs two crucial questions: 1) was there an enrichment?; and 2) if so, was it unjust? Some intermediate principles are required to give substance to the highly abstract concept of unjust enrichment. ${ }^{24}$ The cases do not provide any such principles. ${ }^{25}$ Without supplementation, "unjust enrichment" is a conclusory label that judges affix when they have decided, for whatever reason, to allow the plaintiff to recover.

\section{B. Filling Contractual Gaps}

Since the common law employs the concept of hypothetical contract in a closely analogous situation, it is logical to turn to a hypothetical contract theory as a source of intermediate principles. The hypothetical contract

19. E.g., Maxwell v. Maxwell, 189 Iowa 7, 177 N.W. 541 (1920) (one who has another arrested for insanity bears burden of showing person arrested was both insane and dangerous in subsequent civil suit); Clayton v. New Dreamland Roller Skating Rink, Inc., 14 N.J. Super. 390, 82 A.2d 458 (1951) (jury may find rink official liable for negligent attempt to set broken arm).

20. Criminal liability might arise if, for example, a would-be rescuer interferes with an undercover police officer making a lawful arrest. See People v. Young, 11 N.Y.2d 274, 183 N.E.2d 319, 229 N.Y.S.2d 1 (1962) (defendant properly convicted of assault for using non-deadly force against plainclothes policeman trying to make lawful arrest). But see State v. Chiarello, 69 N.J. Super. 479, 174 A.2d 506 (1961) (defendant not guilty if he reasonably believed his actions necessary to protect third party from unlawful attack).

21. Recovery has been allowed under the Roman law doctrine of negotionum gestio ("management of another's affair"). See Dawson, Negotiorum Gestio: The Altruistic Intermeddler (pts. 1 \& 2), 74 HARv. L. Rev. 817, 1073 (1961) (arguing that negotiorum gestio should not be transplanted into common law).

22. See G. Gilmore \& C. Black, The Law of Admiralty 532-85 (2d ed. 1975). The rules of admiralty permit no recovery for saving life, however, unless property is also saved. See generally Friedell, Compensation and Reward for Saving Life at Sea, 77 MICH. L. REv. 1218, 1263-87 (1979) (suggesting that courts should be allowed to make awards for pure life salvage).

23. See, e.g., Western Coach Corp. v. Roscoe, 133 Ariz. 147, 154, 650 P.2d 449, 456 (1982) ("well established that a person who has been unjustly enriched at the expense of another is required to make restitution to the other"); Cecio Bros., Inc. v. Greenwich, 156 Conn. 561, 564-65, 244 A.2d 404, 405-06 (1968) (One who unjustly enriches himself at the expense of another should be required to make restitution.).

24. See Restatement of Restitution ch. 1 note (unjust enrichment "too indefinite to be of value in a specific case . . . or not universally applied"); 3 W. PAGE, ThE LAW of Contracts $\S$ 1503, at 2567 (2d ed. 1920) (unjust enrichment principle "so vague as to give no help in solving cases as they arise").

25. The Restatement of Restitution allows restitution for unsolicited benefits if the benefit was necessary to protect the interests of others or of third parties. RESTATEMENT OF RESTITUTION, supra note $1, \S 112$. As an intermediate principle, however, this is nearly as indeterminate as the unjust enrichment principle itself. 
idea is used to justify the routine and uncontroversial ${ }^{26}$ process of judicially implying terms missing from express contracts. ${ }^{27}$ In a typical gapfilling situation, the state of the world at the time of performance differs greatly from what the parties had assumed it would be, and therefore the court struggles to apply the contract to conditions that it was not designed to cover. $^{28}$ In many gap-filling situations, neither party foresaw the changed conditions. ${ }^{28}$ In such cases the court often imposes a term it believes the parties would have agreed to, had they foreseen the contingency ${ }^{30}$ - that is, the court imposes a hypothetical agreement.

Gap-filling situations are closely analogous to the unsolicited benefit cases, even though there is no pre-existing contractual relationship in the latter cases. The mere fact that in a gap-filling situation the parties actually agreed to some contractual terms does not necessarily indicate that they would have agreed to other terms imposed by a court. ${ }^{31}$ In fact, there is no less basis for hypothetical agreement in unsolicited benefit cases, in

26. The practice has been endorsed even by commentators strongly committed to the protection of individual autonomy. See C. FrIED, Contract as Promise 69 (1981) ("irrational" not to fill gaps in contracts); Epstein, Private-Law Models for Official Immunity, 42 LAw \& CoNTEMP. ProBs. 53, 55 (1978) (When a tort occurs in the course of a consensual relationship, the court must "approximate the risks which each of the parties would have assumed if they had reached an express agreement allocating them.").

27. As the rule that "material" terms (specifying subject matter, price, payment terms, quality, quantity, duration, and work to be done) must be definite has been undercut, gap-filling has been employed in a widening variety of situations. See U.C.C. § 2-204(3) (1978) ("Even though one or more terms are left open a contract for sale does not fail for indefiniteness if the parties have intended to make a contract and there is a reasonably certain basis for giving an appropriate remedy."); $1 \mathrm{~A}$. CoRBIN, supra note $1, \S \S 95-100 ; 1$ S. Williston, supra note 3 , $\S 38-48$.

28. Other gap-filling situations raise only evidentiary questions, because the parties had some actual intention as to the contingency. They may have intended the court to imply a term, if the contingency arose; they may have intended the court to imply a term to cover any unforeseen contingency which arose. This "global" intention is common: The court will read into a contract the whole body of contract law, including the doctrines of mistake, frustration, and impossibility, unless the parties specifically provide otherwise. On the other hand, the parties may have intended the court not to imply any terms. The court's task in these cases is to determine the parties' actual, rather than hypothetical, intentions.

29. In deciding whether they are faced with a contractual gap, judges consider whether the contingency was foreseeable. See Lloyd v. Murphy, 25 Cal. 2d 48, 54, 153 P.2d 47, 50 (1944); E. FARNSWORTH, supra note $5, \S 7.16$, at 522 .

30. See Prudential Ins. Co. v. Gray Mfg. Co., 328 F.2d 438, 445 (2d Cir. 1964) (Friendly, J., concurring) (concluding that, if a condition had been requested, it would have been assented to); $\mathrm{J}$. Bentham, A General View of a Complete Code of Laws, in 3 Works of Jeremy Bentham 191 (J. Bowring ed. 1843) (Judges should remedy "the shortsightedness of individuals, by doing for them what they would have done for themselves, if their imagination had anticipated the march of naturc."); Farnsworth, Disputes Over Omission in Contracts, 68 Colum. L. REv. 860, 860 (1968) ("Characteristically, common law courts have dealt with problems arising out of what the parties did not say about a situation by purporting to determine what the parties would have said if they had said something about it.").

31. A standard economic justification of gap-filling is that it saves the parties the expense of negotiating an endless series of terms to cover remote contingencies. See R. POSNER, supra note 1 , at 69 (contract law reduces transaction costs by supplying a set of normal terms the parties need not negotiate expressly). The fact that the contingency was remote will not support the conclusion that the partics would have agreed to the term the court imposes. 
general, ${ }^{32}$ than in gap-filling situations. In the latter cases, the parties might have agreed to the term the court imposes, or they might have agreed to some other term, or they might have agreed to no term at all, thus allowing the loss to lie where it fell. ${ }^{33}$

\section{A Model of Hypothetical Contract}

A court is justified in imposing a hypothetical contract on the parties only if there is evidence that the parties would have agreed, had they been able, to the terms and conditions the court imposes. ${ }^{34} \mathrm{~A}$ court should not impose liability unless it finds that: 1) high transaction costs precluded negotiation of an express contract; and 2) the hypothetical contract is Pareto-superior. Together, these two conditions supply content to the principle of unjust enrichment and explain many of the unsolicited benefit decisions.

\section{A. Prohibitive Transaction Costs}

A court should not impose a hypothetical contract if the parties could have negotiated an express agreement, for two reasons. First, the fact that the parties might have negotiated an express contract, but did not, suggests that at least one of them did not wish to be contractually bound. ${ }^{35}$ The second reason is more fundamental. At least one purpose of con-

32. Although the express agreement is an additional source of general information about the way in which the parties tended to allocate risks, by hypothesis that information is not decisive.

33. Commentators have recognized this indeterminacy, and concluded that judges fill gaps with "equitable" or "reasonable" terms. See, e.g., 1 A. CoRbIN, supra note 1, § 19, at 46-47; E. FARNSWORTH, supra note 5, $\$ 7.16$, at 524-25; Corbin, Conditions in the Law of Contracts, 28 YALE L.J. 739, 743-44 (1919).

34. According to the theory set forth in this Note, a hypothetical contract may be imposed if, at the moment the benefit was conferred, the beneficiary would have agreed to pay for the benefit. It is also possible to imagine a hypothetical contract among all citizens to render mutual assistance, made before any particular opportunity to confer benefits has arisen. This broader notion of hypothetical cotract has been employed by a number of legal commentators, notably Richard Posner. See R. PosNer, The Economics of Justice 88-115 (1981); see also Polinsky, Probabilistic Compensation Criteria, 86 Q.J. ECON. 407, 409-12 (1972) (possibility of applying Pareto test to several redistributions simultaneously). Posner uses the notion of ex ante compensation to justify many tort liability rules. He analogizes a pedestrian who is hit by a non-negligent motorist to a losing ticketholder in a fair lottery. R. Posner, supra, at 98 . This is a false analogy, however, because individuals can choose to enter a lottery, but they generally cannot choose whether or not to be governed by legal rules.

The related notion of implicit in-kind compensation has appealed to many scholars, including some who are strongly opposed to interference with individual liberty. See, e.g., C. FRIED, AN ANATOMY of Values 187-91 (1970) (each individual is exposed by others to a certain amount of risk, but in turn exposes others to a roughly equivalent amount of risk); Epstein, Nuisance Law: Corrective Justice and its Utilitarian Constraints, 8 J. LEgal STud. 49, 84-85 (1979) (some nuisances permissible because each individual imposes equivalent inconvenience on others); Fletcher, Fairness and Utility in Tort Theory, 85 HaRv. L. REv. 537 (1972) (arguing tort liability should be based on whether parties to lawsuit impose reciprocal risks on each other).

35. Failure to contract is not conclusive, however, because the parties may have failed to contract out of simple inadvertence. 
tract-arguably the primary purpose-is to give legal effect to individuals' orderings of their own affairs. ${ }^{36}$ This basic purpose is defeated if the imposition of a hypothetical contract short-circuits a potential express contract. $^{87}$

Although the transaction costs requirement limits the scope of the hypothetical contract theory, the theory is still useful. In practice, many express contracts are impossible because transaction costs are prohibitive. There are so many potential "rescue" situations and "rescuers" that it would be impossible ex ante to negotiate contracts covering all potential rescues. $^{38}$ Moreover, once a rescue situation arises, there may be no time to bargain. ${ }^{39}$ One of the parties may be unconscious, ${ }^{40}$ incompetent, ${ }^{41}$ or simply unavailable. ${ }^{42}$ Thus the transaction costs standing in the way of

36. See C. FrIED, supra note 26, at 16 (obligation to keep promises grounded in individual autonomy rather than utility); F. Kessler \& G. Gilmore, Contracts 2-6 (2d ed. 1970) (contract viewed as means to achieve freedom). If individuals were entitled to force others into transactions, they would have, in essence, a private right of eminent domain. See Calabresi \& Melamed, Property Rules, Liability Rules, and Inalienability: One View of the Cathedral, 85 HARv. L. Rev. 1089, 1106-08 (1972) (discussing eminent domain as paradigm of liability rule).

Some scholars have argued that contract law should serve quite different ends. Some argue, for example, that contract law should reflect society's distributional preferences. See, e.g., Kronman, Contract Law and Distributive Justice, 89 YALE L.J. 472, 472-73 (1980) (society's distributional preferences must be taken into account for contract law to have "minimal moral acceptability"); Michelman, Norns and Nornativity in the Economic Theory of Law, 62 MINN. L. Rev. 1015, 1016-37 (1978) (housing code regulation of rental contracts justifiable as a redistributive measure even if economically inefficient). These commentators do not deny that enforcing private agreements is a core purpose of contract law. They merely deny that it is the only purpose. See Kronman, supra at 472 ("nearly universal agreement" among contract scholars that a legitimate purpose of contract law is to enforce private agreements; redistribution a possible additional purpose).

Other scholars go further, and argue that freedom of contract is merely an endpoint on a spectrum of state-imposed duties. E.g., Kennedy, Form and Substance in Private Law Adjudication, 89 HaRv. L. REv. 1685, 1778 (1976) (judges should create "altruistic order" in context of contract law); Unger, The Critical Legal Studies Movement, 96 HARv. L. Rev. 561, 639-48 (1983) (obligations arise primarily from relationships of mutual dependence that have been only incompletely shaped by stateimposed duties or explicit and perfected bargains). Hypothetical contract theory has little appeal if this position is accepted. If express agreement is unimportant, so is hypothetical agreement.

37. Economists favor express contract for a third reason-allocative efficiency. Individuals are assumed to be the best judges of their own preferences; hence any other method of allocating resources will result in less total welfare. The preference is not absolute, however, because the efficient solution may be non-contractual if transaction costs are very high. Posner, $A$ Theory of Negligence, $1 \mathrm{~J}$. LEGAL. Srud. 29, 74-77 (1972).

38. It would be prohibitively expensive, for example, for a shipowner to contract with every ship that might be able to effect a rescue if a hazardous situation develops during the voyage. See Landes \& Posner, supra note 1, at 90-91 n.18.

39. See, e.g., Bartholomew v. Jackson, 20 Johns. 28 (N.Y. Sup. Ct. 1822) (wheat stack threatened by fire); Glenn v. Savage, 14 Or. 567, 13 P. 442 (1887) (lumber fallen in river).

40. See, e.g., Cotnam v. Wisdom, 83 Ark. 601, 104 S.W. 164 (1907) (doctor recovers for assisting patient who dies without regaining consciousness); In re Crisan's Estate, 362 Mich. 569, 107 N.W.2d 907 (1961) (hospital recovers for same).

41. See Schaefer v. Schaefer, 255 Mass. 175, 151 N.E. 119 (1926) (allowing recovery for services to insane person). But $c f$. In re Rhodes, 44 Ch.D. 94 (Ch. App.) (1890) (holding services to insane person intended as a gift).

42. See, e.g., Chase v. Corcoran, 106 Mass. 286 (1871) (owner of drifting boat unknown); Berry v. Barbour, 279 P.2d 335 (Okla. 1954) (beneficiary away in Europe). 
contracts to rescue frequently are enormous. When prohibitive transaction costs block an express contract, a hypothetical contract does not necessarily override individual preferences. A hypothetical contract may, on the contrary, increase individuals' satisfaction by allowing them to make exchanges they would have made themselves but for high transaction costs.

\section{B. Pareto-superiority}

The essence of contract is agreement. ${ }^{43}$ Contract derives its normative force from the principle that it is fair to hold parties to their own bargains. ${ }^{44}$ Hence there can be no hypothetical contract without a proxy for actual agreement. There must be a reason to conclude that the parties would have agreed to the terms imposed by the court if transaction costs had been lower. ${ }^{45}$

In general, a person would agree to a transaction that makes him better off. ${ }^{48}$ For both parties to agree, both must be made better off. ${ }^{47}$ If both parties are made better off, then the transaction is Pareto-superior by definition. ${ }^{48}$ Hypothetical contracts, then, must be shown to be Paretosuperior. ${ }^{48}$ This formulation of the hypothetical contract model gives con-

43. U.C.C. § 1-201(11) (1978) (contract is legal obligation resulting from parties' agreement). Other authorities define contract in promissory terms. See RESTATEMENT (SECOND) of Contracts $\S 1$ (1981) ("A contract is a promise . . . for the breach of which the law gives a remedy . . . ."); 1 S. Willisron, supra note 3 , at $\S 1$. The difference is irrelevant here: If one promises to do something, one agrees to do it.

44. See C. FRIED, supra note 26 , at 14-21.

45. There are two questions: 1) would the parties have agreed, if transaction costs had been lower? and 2) does the fact that the parties would have agreed justify judicial imposition of the terms to which they would have agreed? Pareto-superiority provides the basis for an affirmative answer to the first question. This Note assumes without argument that the answer to the second question is "yes." See infra note 59 (summarizing Dworkin's argument that "micro" hypothetical contracts have at least "pale binding force").

46. This assumes individuals are maximizers of their own satisfactions. See infra note 64 .

47. If the transaction leaves a party no better off but no worse off, the party is indifferent as to whether the transaction takes place. The hypothetical contract theory, by adopting the Pareto criterion, assumes that individuals would agree to transactions which left their overall position unchanged. This is an arbitrary assumption, but the assumption that individuals would not agree to such transactions is equally arbitrary.

48. See supra note 4 (defining Pareto-superiority). This is not to say that Pareto-superiority guarantees that each individual will benefit from every transaction. Any contract that has a non-negative expected value at the moment it is hypothetically made satisfies the Pareto criterion. See Polinsky, supra note 34, at 407-08. Relaxing the requirement of non-negative outcomes in favor of mere nonnegative expectations might seem to expand the hypothetical contract principle almost endlessly. The scope of the hypothetical contract theory, however, is limited by individuals' different attitudes toward risk. See infra note 77.

49. Economists generally agree that the requirement of Pareto-superiority is too strict to justify many redistributions in practice. See, e.g., G. CALABresi \& P. BobBit, Tragic Choices 83-85 (1978) (Pareto superiority virtually useless). But see P. Samuelson, Foundations of Economic ANALYSIS, 146-56 (enlarged ed. 1983) (possibility of determining revealed preferences if certain restrictive conditions are met).

The Pareto criterion is more powerful, however, in the context of hypothetical contracts. One set of problems, involving third-party effects, can be virtually eliminated. Insofar as parties to an express 
tent to the abstract principle of unjust enrichment: An individual is unjustly enriched if he receives a benefit that he would have been willing to pay for, ex ante, absent transaction costs. The Pareto criterion provides an evidentiary basis for the conclusion that the party would have been willing to pay.

The Pareto criterion protects individuals from judicially-imposed contracts they would be unlikely to make for themselves. Richard Posner's competing theory of wealth maximization does not afford this protection. ${ }^{50}$ Posner rejects the relatively restrictive Pareto criterion: He would permit any transaction that increases aggregate social wealth. ${ }^{51}$ Although wealth maximization is a "potential Pareto criterion," in the sense that those who gain from a wealth-maximizing transaction could fully compensate the losers, Posner's criterion does not require compensation in fact. ${ }^{\mathbf{5 2}}$ Hence the wealth-maximization principle would permit judges to impose hypothetical contracts even though some individuals would thereby be made worse off. But individuals are unlikely to agree to being made worse off, as some of Posner's critics have pointed out. ${ }^{\text {ss }}$ Although Posner dismisses this criticism with the remark that "only a fanatic would insist that una-

agreement are free to ignore externalities-and they generally are, unless the contract is found violative of public policy, see Sternaman v. Metropolitan Life Ins. Co., 170 N.Y. 13, 19, 62 N.E. 763, 764 (1902) (public policy limitations on express contracts)-it is reasonable to ignore externalities in finding hypothetical contracts.

50. Posner has argued that common law rules generally both do and should maximize aggregate social wealth. Compare R. POSNER, supra note 34, at 6 (1981) (asserting that efficiency is an adequate concept of justice) with Posner, Some Uses and Abuses of Economics in Law, $46 \mathrm{U}$. CHI. L. REv. 281, 287-91 (1979) (Posner's main concern positive, not normative).

51. R. Posner, supra note 34, at 92-99. Posner recognizes that his wealth-maximization concept is functionally equivalent to Kaldor-Hicks optimality. Id. at 91-92. A transaction is Kaldor-Hickssuperior if one party gains more than the other loses. A distribution is Kaldor-Hicks optimal if no Kaldor-Hicks-superior redistributions are possible. Critics have argued that Posner is wrong to identify wealth-maximization with Kaldor-Hicks optimality. See Hammond, The Economies of Justice and the Criterion of Wealth Maximization (Book Review), 91 YALE L.J. 1493, 1496 (1982) (reviewing R. POSNER, The Economics of Justice (1981)) (wealth maximization incorporates income distribution by evaluating ability to pay). The differences are irrelevant to this discussion, since both wealth-maximization and Kaldor-Hicks optimality aim at maximizing a social aggregate, without regard to whether some individuals are made worse off.

52. See R. PosNer, supra note 34 , at 91 . This difference has led one commentator to conclude that "[a]ctual markets embody respect for the individual and his choice, whereas [wealth-maximizing] hypothetical markets entail the sacrifice of the interests of some individuals in the name of maximization." Weinrib, Utilitarianism, Economics, and Legal Theory, 30 U. ToRONTo L.J. 307, 322 (1980).

Posner's discussion of wealth maximization as a proxy for agreement is ambiguous. See R. POSNER, supra note 34, at 88-115. He may believe that each individual benefits in the long run from consistent application of the wealth-maximization principle. That is, Posner may believe that a single, global, universal hypothetical contract to wealth-maximize in every situation is Pareto-superior to the absence of such a contract. Posner does not offer any evidence to show that such a contract is Paretosuperior, however. Alternatively, Posner may believe that wealth maximization is a sufficient condition for hypothetical consent.

53. See, e.g., Dworkin, Is Wealth a Value?, 9 J. Legal STud. 191, 202 (1980) ("crazy" for individuals to choose to maximize social wealth as surrogate for individual wealth); Kronman, supra note 9, at 237 (1980) (Posner's examples have moral appeal only because they meet Pareto criterion). 
nimity be required," catory force from agreement. "I would not have agreed," if true, is a fatal response to a proposed hypothetical agreement, even if the failure to agree is based on idiosyncratic or accidental characteristics of the individual. ${ }^{.5}$ While many legal rules impose liability on individuals who would not have agreed to be made liable, it is an abuse of language to call such liability contractual.

\section{When is the Contract Pareto-superior?}

Posner's wealth-maximization criterion is unsatisfactory on another level: Wealth is not the only possible goal. Individuals may prefer to trade off wealth for some non-pecuniary good they value. In order to preserve individual autonomy, the hypothetical contract theory must require clear evidence that a court-imposed transaction makes the involuntary parties subjectively better off, not merely that it increases their wealth. ${ }^{58}$ Some critics of hypothetical contract theory argue that this is impossible because human preferences are so diverse, arguing, for example, that individuals care how their preferences are satisfied: ${ }^{67}$ They may prefer to benefit from their own efforts rather than from the unsolicited efforts of others. ${ }^{68}$ The hypothetical contract model must acknowledge these preferences, even if they are idiosyncratic. ${ }^{58}$

54. R. POSNER, supra note 34 , at 97.

55. See infra pp. 425-26 (discussing treatment of idiosyncratic preferences).

56. That is, the Pareto criterion must measure utility rather than wealth. Posner has canvassed the difficulties raised by any attempt to measure utility. See R. POSNER, supra note 34, at 51-60.

57. See Coleman, The Nomnative Basis of Economic Analysis: A Critical Review of Richard Posner's The Economics of Justice (Book Review), 34 StaN. L. Rev. 1105, 1117-31 (1982). Coleman argues for a fuller specification of individual utility functions, including non-pecuniary sources of satisfaction. Coleman apparently accepts the basic economic assumption that individuals are rational maximizers of their satisfactions, see R. POSNER, supra note 34 , at $1-2$ (assumption is economist's "basic analytical tool").

58. Coleman, supra note 57 , at 1126-27.

59. One possible solution to the problem of human diversity is to deprive individuals of information about their particular situations. Then only a single "representative" individual remains. If that individual would agree, then all would agree. John Rawls calls this solution the "veil of ignorance." J. RAwLS, A Theory OF JUSTICE 136-42 (1971). Rawls is the most recent contributor to a tradition of political theory which attempts to justify the civil state on the basis of a hypothetical social contract. Sep J. Locke, Two Treatises of Government (ed. J. Gough 1961) (1st ed. London 1690); J. Rousseau, The Social Contract (L. Crocker ed. 1967) (1st ed. Paris 1762). See generally J. Gougr, The Social Contract (2d ed. 1957) (discussing the contractarian tradition). Hypothetical contract in political theory usually is justified by pointing out that an express contract involving so many parties is impossible.

Rawls" "veil of ignorance" solution is controversial even for a "macro" social contract, the choice of basic principles of social justice. See R. NozIcK, supra note 9, at 198-213 (principle of fair resource distribution is historical; any "patterned" distribution principle requires continuous government intervention). The Rawlsian solution has virtually no appeal as a specification of conditions for "micro" hypothetical contracts made against the background of an existing set of social arrangements. See R. Dworkin, TAKING RIGHTS SERIOUSLY 151-52 (1977) (analogy to poker game: player is not obligated to throw in a winning hand when a card is discovered missing from the deck just because he 
Two factors, however, simplify the undertaking. One is that, despite idiosyncracy, some human preferences are nearly unanimous. ${ }^{80}$ The second is that individuals often reveal their preferences through actions. ${ }^{61}$ In some situations, then, a court can conclude with great confidence that the parties would have agreed to the terms it imposes.

The Pareto-superiority requirement incorporates a respect for preferences if they have been manifested. Although some subjective preferences and values are not provable, even express contract doctrine rejects the view that the parties are bound only if they subjectively intend to be bound. ${ }^{62}$ To the extent that the hypothetical contract model permits mistakes about parties' subjective preferences, these mistakes are no more serious than those permitted by the law of express contract. ${ }^{63}$

\section{Hypothetical Contracts to Save Life}

Individuals desire continued existence, not only as an end in itself, but because a person is likely to be the most effective agent for carrying out his own projects. ${ }^{64}$ Therefore individuals would rather pay for unsolicited life rescues than die, both because they place a high value on their own lives, and because death is the extreme reduction of individual autonomy.

Not all individuals desire to go on living at all times. The hypothetical contract theory, through the Pareto-superiority requirement, respects a preference for death over life if there is evidence for the existence of the

would have agreed to such a rule before play began). Since parties to an express contract do not ignore information about their own preferences, parties to a hypothetical contract should not be deprived of that information.

This Note does not attempt to compare the "macro" hypothetical contracts of the political theorists to the "micro" hypothetical contracts considered here. Dworkin argues that hypothetical contract has no "pale binding force" in the social contract situation, but may be important in "micro" situations if there is reason to believe the party's "will was inclined toward the decision at the time and in the circumstances that the decision was taken." Id. at 152.

60. For example, the preference to go on living seems to be nearly unanimous.

61. See P. SAmuelson, supra note 49, at 146-56 (revealed preference theory).

62. Express contract doctrine relies on objective behavior, rather than the subjective meeting of the parties' minds. Hotchkiss v. Nat'l City Bank, 200 F. 287, 293 (S.D.N.Y. 1911), aff'd, 201 F. 664 (2d Cir. 1912), aff d, 231 U.S. 50 (1913). Similarly, hypothetical contracts should be imposed when objective evidence indicates that the parties would have agreed. Individuals typically reveal their preference to go on living or increase their stock of wealth through their behavior considered as a whole. Cf. $P$. SAMUELSON, supra note 49 , at 146-56 (revealed preference theory).

63. Even though express contract may be viewed as the paradigm of an autonomous transaction, the need to interpret express contracts will inevitably lead to some departures from the subjective intentions of the parties. Cf. Towne v. Eisner, 245 U.S. 418, 425 (1918) (Holmes, J.) ("A word . . . is the skin of a living thought and may vary greatly in color and content according to the circumstances and the time in which it is used."). An express contract might, however, provide some additional objective evidence of the parties' preferences.

64. The proposition assumes that individuals have goals. Arguably, having a goal implies having a desire to pursue those means likely to achieve it. This assumption, that individuals are "minimally rational," is crucial to Rawls' theory of justice. See J. RawLS, supra note 59, at 142-50; see also K. Arrow, Social Choice and Individual Values 19-21 (2d ed. 1963) (discussing this paradigm of rationality); A. SEN, supra note 4 , at 16-20 (same). 
preference. ${ }^{65}$ Similarly, other people may prefer to live but place a very low value on their lives. Again, there is likely to be some objective evidence of the lower bound of that subjective value. ${ }^{68}$

\section{Hypothetical Contracts to Save Property}

Restitution for saving money or other highly liquid ${ }^{67}$ property satisfies the Pareto criterion in all circumstances. Most individuals would pay a small amount of money in order to preserve a larger amount of money. Those who would not may simply refuse to accept the cash; they are then no worse off than if no one had attempted to confer a benefit on them. ${ }^{68}$ Acceptance of the benefit demonstrates that the Pareto criterion has been subjectively met. If, on the other hand, the beneficiary cannot costlessly refuse the benefit, because it is not easily severable from his other assets, then the Pareto criterion would not necessarily be met and the hypothetical contract theory would deny recovery. ${ }^{69}$

\section{Altruism and Risk Preference}

Altruistic individuals-those who are willing to confer benefits without compensation $^{70}$ - pose an additional problem for hypothetical contract theory. Beneficiaries naturally would prefer a free benefit to one they are obligated to pay for. ${ }^{11}$ Even altruists are likely to claim compensation if they are entitled to it. ${ }^{72}$ Since there is usually no way to tell, either ex post or ex ante, whether the plaintiff is an altruist, ${ }^{73}$ the Pareto criterion for-

65. See infra notes 102-03 (discussing common law treatment of idiosyncratic preferences).

66. Such objective evidence may include a life insurance policy or expenditures for food or medical care.

67. An asset is more liquid if it has more of the characteristics of cash. See P. SAmuelson, ECONOMICs 328-31 (11th ed. 1980) (discussing liquidity preference schedule).

68. Such contracts can actually be viewed as express contracts. The performing party makes a "reverse unilateral offer" by conferring the benefit. The beneficiary's acceptance or rejection of the benefit constitutes an express acceptance or rejection of the offer. See J. Calamari \& J. Perilio, supra note 3, § 2-14, at 54-55 (defining reverse unilateral contracts). Except for unsolicited merchandise delivered by mail, see 39 U.S.C. $\S 3009$ (1982), silence generally constitutes acceptance in the law of contracts if the goods are returnable. See $1 \mathrm{~A}$. CoRBIN, supra note $1, \S 75$, at $316 ; 1 \mathrm{~S}$. WILLISTON, supra note $3, \S 91 \mathrm{D}$, at 332 .

69. The defendant might find it costly to pay an immediate cash judgment because he is short of cash. The defendant might be worse off even in the long-run if it is very costly for him to borrow money, or if he has other very attractive uses for his money.

70. Altruism is discussed in Landes \& Posner, supra note 1, at 93-100.

71. Even if beneficiaries preferred to pay for the benefit, they could make the payment voluntarily. They would then enjoy the additional benefit of being regarded as generous.

72. Most altruists are "imperfect" altruists. That is, they would prefer an extra dollar in their own bank account to an extra dollar in the beneficiary's bank account. While the rescuer could decline to claim compensation, and thereby benefit by being regarded as an altruist, claiming restitution is not inconsistent with willingness to perform an altruistic rescue. Landes \& Posner, supra note 1, at 93-95.

73. Ex ante, the question is likely to be open, since the rescuer has not yet made a decision. Ex post, the rescuer has an incentive to testify that he intended to charge in order to recover. 
bids imposing a hypothetical contract if the beneficiary might have decided not to purchase the benefit in hopes of getting it for nothing. ${ }^{74}$ The possibility of altruism, therefore, obstructs most hypothetical contracts. In fact, the problem of altruism explains the common law's refusal to award restitution to those who did not intend to charge for their services. ${ }^{75}$

The possibility of altruism does not, however, bar hypothetical contracts to save lives. This is easily shown by examining the possibility of altruistic life rescue from the standpoint of the beneficiary at the time the hazard arises. If transaction costs were zero, the beneficiary would decide whether to pay for a life rescue based on his assessment of the probability that the potential rescuer is an altruist. The beneficiary would be extraordinarily unlikely to reject the contract, though, because he would be highly uncertain about the actual probability that the other party is an altruist. This would increase his incentive to pay to ensure a rescue. Moreover, the benefit of life rescue is so large in relation to the probable cost that the possibility of altruism would probably have only a marginal effect on the rescuee's risk-benefit calculation. ${ }^{76}$

The conclusion does not change when risk preference is taken into account. ${ }^{77}$ Risk avoiders would be particularly inclined to purchase rescue services. Risk lovers might prefer to chance not being rescued by an altruist at no cost. Given the huge disparity between cost and benefit, and the beneficiary's level of uncertainty, however, the possibility that one would be so risk-loving as to refuse to pay is extremely remote. Once again, an individual with such idiosyncratic preferences will undoubtedly have provided evidence of them in the past.

\section{The Hypothetical Contract Theory and the Common LAW OF RESTITUTION FOR UNSOLICITED BENEFITS}

Judges and scholars have rejected hypothetical contract as a supplement to the unjust enrichment principle. ${ }^{78}$ But since the unsolicited benefit cases

74. The contract would be Pareto-superior if:

$$
B-C>p(B) \text {, }
$$

where $B$ is the value of the benefit, $C$ is the cost of paying for benefit, and $p$ is the probability that the rescuer is an altruist.

75. See infra p. 429.

76. Social psychologists have suggested that altruistic behavior is often unlikely even in easy rescue situations. See B. Latané \& J. Darley, The Unresponsive Bystander (1970).

77. Some individuals are risk-averse. They prefer less uncertainty to more, other things being equal. Other individuals are risk-lovers. Individuals may behave like risk-lovers for psychological reasons. See G. Galabresi, The Costs of Accidents 55-58 (1970) (individuals may lack information, be unable to conceive of themselves suffering an injury, or favor short-term over long-term utility). Since the hypothetical contract is not made until a hazardous situation has actually arisen, the theory does not paternalistically override these psychological biases. For a general discussion of uncertainty, see P. LAyard \& A. Walters, Microeconomic Theory 351-90 (1978).

78. E.g., Restatement (SECOND) of Restitution, supra note $1, \S 1$ comment a (unjust en- 
are largely consonant with the model of hypothetical contract, ${ }^{79}$ judges appear to be influenced by contractual principles in spite of what they say. The hypothetical contract approach explains many of the unsolicited benefit cases. ${ }^{80}$ Moreover, the hypothetical contract theory clarifies the analysis of all the unsolicited benefit cases by making explicit the contractual principles which have been tacitly applied under the rubric of "unjust enrichment."

The hypothetical contract theory explains the common law rules governing recovery for unsolicited benefits. The common law denies restitution if the plaintiff was an "officious intermeddler,"81 intended to confer the benefit gratuitously, ${ }^{82}$ or conferred an unmeasurable benefit. ${ }^{83}$ The first limitation is equivalent to a requirement of prohibitive transaction costs. The second and third limitations embody the Pareto-superiority condition. The amount of recovery allowed is also consistent with hypothetical contract theory.

\section{A. Officiousness}

Legal hostility toward "officiousness" incorporates the high transaction costs condition. ${ }^{84}$ Courts use the vague term "officious" to bar recovery if the plaintiff could have negotiated with the defendant before conferring the benefit. For example, a worker who performs repairs on a house without a contract is barred, as an officious intermeddler, from recovering his costs, even if he increases the value of the house. ${ }^{85}$ But a court may permit recovery if repairs are necessary to prevent a loss, and if the owner cannot be contacted. ${ }^{8 \boldsymbol{B}}$

richment priciple is independent of both contract and tort principles); supra note 3 (restitution not based on intentions, actual or hypothetical, of parties).

79. See infra pp. $428-433$.

80. Some cases further a policy, also largely unarticulated, of encouraging inexpensive private discharge of public duties. Providing necessities to children and burying the dead, for example, further such a policy. See supra notes 12-13.

81. See Restatement of Restitution, supra note $1, \S 2$ comment a ("Officiousness means interference in the affairs of others not justified by the circumstances under which the interference takes place."); Hope, supra note 12, at 25-27.

82. See Restatement of Restitution, supra note 1, § 116; Wade, supra note 1, at 1190-94.

83. Wade, supra note 1 , at 1186-90.

84. See Landes \& Posner, supra note 1, at 89-90.

85. See Stees v. Leonard, 20 Minn. 448 (1874); Restatement of Restrtution, supra note 1, § 112 illus. 3.

86. See Berry v. Barbour, 279 P.2d 335 (Okla. 1954) (fire burned holes in roof of warehouse while owner in Europe). In Berry, however, the plaintiffs were already under contract to repair the warehouse, so the court was able to find the emergency repairs within the "implied" scope of the agency. Id. at 337-38. 


\section{B. Intent to Charge}

The common law allows recovery for an unsolicited benefit only if the rescuer intended to charge. ${ }^{87}$ This requirement partially incorporates the Pareto condition, by denying recovery to altruists. ${ }^{88}$ The common law rule would dispose of the problem of altruism, except that it may be impossible to determine whether individuals truly intended to assist gratuitously. ${ }^{80}$ The Restatement establishes a set of presumptions to deal with this problem in emergency situations: Professionals are presumed to intend to charge; non-professionals are presumed not to intend to charge. ${ }^{90}$ These presumptions are consistent with hypothetical contract theory. Professionals, by definition, perform services for profit. Since professionalism is a good but imperfect proxy for non-altruism, ${ }^{91}$ a set of rebuttable presumptions is consistent with the hypothetical contract theory. ${ }^{92}$

\section{Measurable Benefit}

The common law denies recovery for an unsolicited benefit unless the benefit is measurable in dollars. ${ }^{93}$ This rule, along with the requirement of an intention to charge, satisfies the Pareto condition. ${ }^{94}$ If the benefit is

87. See Ryan v. Johnson, 220 Md. 70, 150 A.2d 906 (1959) (accepting defense that plaintiff intended payment of bills as a gift); RestatEMENT of RestrTution, supra note $1, \S \S 116(\mathrm{a})$, 117(d).

88. See supra pp. 426-27 (discussion of altruism).

89. See supra note 73 .

90. See Restatement of Restitution, supra note $1, \S 114$ comment c.

91. Some professionals, such as professional salvors at sea, almost never rescue gratuitously. In fact, the legal entitlement to compensation calls forth resources devoted to professional maritime salvage. Cf. G. GiLmore \& C. BLACK supra note $22, \S 8-4$, at 541-46 (professional salvors allowed to recover without regard to their intent to charge). Other professionals, such as physicians, derive most of their income from express contracts, and so might undertake some gratuitous rescues without greatly reducing their income. The widespread enactment of so-called "Good Samaritan statutes," which immunize physicians, and sometimes others, from negligence in providing emergency medical assistance, suggests that many physicians are not altruistic enough to rescue if they might be sued for malpractice. See Note, Good Samaritans and Liability for Medical Malpractice, 64 Colum. L. REv. 1301, 1302 (1964).

92. Presumptions are a classic legal response to uncertainty. See McCormick, MCCormick on EvidENCE $\$ 343$ (3d ed. 1984). Some cases and commentators suggest that the presumption that nonprofessionals do not intend to charge should be irrebuttable. See Bartholomew v. Jackson, 20 Johns. 28 (N.Y. Sup. Ct. 1822); Glenn v. Savage, 14 Or. 567, 13 P. 442 (1887); F. Woodward, ThE LAw of QUASI ConTRACTs 314 (1913). Hypothetical contract theory suggests this rule is too strict. Plaintiffs should be allowed to carry the burden, if they can, of showing they would not have rescued absent a right to recover. Cf. R. Goff \& G. Jones, The LAw of Restitution 271 (2d ed. 1978) (burden of showing gratuitous intent should be defendant's).

93. E. FARNSWORTH, supra note 5, 103-04. Physicians' services are a clear example. See, e.g., Cotnam v. Wisdom, 83 Ark. 601, 104 S.W. 164 (1907); In re Crisan Estate, 362 Mich. 569, 107 N.W.2d 907 (1961).

94. Plaintiffs are also barred from recovering if the benefit was incidental to a project plaintiff would have undertaken anyway. See Ulmer v. Farnsworth, 80 Me. 500, 15 A. 65 (1888) (plaintiff cannot recover for unavoidably draining defendant's quarry while draining his own quarry); REStatement of Restitution, supra note $1, \S 106$. This rule is also consistent with the Pareto criterion, since the plaintiff will provide the benefit whether or not he is entitled to compensation. 
measurable, the court can determine that the benefits of the transaction exceed the costs.

If there is a market price for the benefit conferred, it is not difficult to show that the Pareto condition is met. The owner presumably valued the property at least as highly as the market does; otherwise, he would have been better off selling the property for its market price. ${ }^{95}$ The court can be confident, therefore, that the owner will not be required to pay more for the rescue than he would have agreed to pay ex ante. ${ }^{96}$

Even though the benefit is clearly worth more than the cost of the judgment, the Pareto condition may not be satisfied if the benefit is conferred in a highly illiquid form ${ }^{97}$ since the beneficiary must pay a judgment in cash. $^{98}$ Judges have recognized this problem in the context of improvements to land, and have fashioned ingenious remedies to handle it. ${ }^{99}$

Courts generally decline to award restitution for nonmarketable benefits. ${ }^{100}$ This is also consistent with hypothetical contract theory. If there is no market for the benefit, courts may overestimate the beneficiary's subjective evaluation of the benefit, thus imposing a contract to which he would not have agreed ex ante.

If the plaintiff has saved the defendant's life, however, restitution satisfies the Pareto condition, even though the benefit is not marketable. ${ }^{101}$ Courts have been faced with a few problem cases involving atypical preferences. A person attempting suicide is expressly revealing a preference for death. ${ }^{102}$ For him, presumably, continued existence has a negative value. Unless the individual later regrets the decision, and is grateful for being saved, hypothetical contract theory would deny recovery. Moreover, some individuals would prefer death to certain types of medical treatment

95. It is possible that the owner valued the property less than the market, but did not sell because of high transaction costs. In that case, however, he is free to refuse the property.

96. For a discussion of how much the beneficiary will be made to pay, see infra pp. 431-32.

97. The best example is an improvement to land. See, e.g., Hardy v. Burroughs, 251 Mich. 578, 232 N.W. 200 (1930); Sykes v. Sykes, 262 Ala. 277, 78 So. $2 d 273$ (1954). See supra p. 426 (discussion of liquidity of benefit).

98. Even so, the beneficiary may be able to borrow against the benefit conferred in order to pay a judgment. But see supra note 69 (cost of borrowing may exceed value of benefit).

99. In Union Hall Ass'n v. Morrison, $39 \mathrm{Md}$. 281 (1873), defendant was given the option of paying a cash judgment or conveying the improved property in return for its unimproved value in cash. In Voss v. Forgue, 84 So. $2 \mathrm{~d} 563$ (Fla. 1956), the defendant was ordered to exchange the improved lot for an unimproved lot.

100. See Restatement of Restitution, supra note $1, \S 1$ comment b (person normally must pay only for pecuniary advantage).

101. See supra pp. 425-26.

102. See Meyer v. Knights of Pythias, 178 N.Y. 63, 70 N.E. 111 (1904) (physician-patient relationship established even though decedent, who had taken rat poison, cursed at physician and ordered him out of the room); Matheson v. Smiley, [1932] 2 D.L.R. 787 (Man. Ct. App.) (surgeon recovers even though patient's wound was self-inflicted). But see Soldiers Memorial Hospital v. Sanford, [1934] 2 D.L.R. 334 (N.S.S.C.) (recovery denied where plaintiff arrested and taken to hospital against his will). 
for religious reasons. ${ }^{103}$ Again, hypothetical contract theory would not allow recovery in these cases. The inconsistent results of the few reported cases suggest that these situations push the hypothetical contract idea to its limits. ${ }^{104}$

\section{Amount of the Award}

Judges have limited recoveries for unsolicited benefits to the cost of the goods or services provided, or to the value of the benefit conferred, whichever is less. ${ }^{105}$ This rule is also consistent with hypothetical contract theory. In general, a Pareto-superior contract is possible if the benefits of performance to the promisee exceed the costs of performance to the promisor. Absent an established market price for the performance, the parties might agree on any price less than the benefit to the promisee but greater than the cost to the promisor. ${ }^{106}$ All such prices are Pareto superior, and so fulfill the requirements of hypothetical contract. A price closer to the promisor's cost of performance, however, gives the promisee more of the surplus from the transaction. This result is preferable because the contract is hypothetical on one side only. The rescuer conferred a benefit voluntarily. Since she was free not to confer the benefit, she is not justified in

103. Courts have considered whether Jehovah's Witnesses may refuse blood transfusions in lifethreatening situations for religious reasons. Compare In re Estate of Brooks, 32 Ill. 2d 361, 205 N.E.2d 435 (1965) (state-appointed conservator may not compel transfusion that will probably save life of adult without minor children if she has steadfastly refused transfusion for religious reasons with knowledge that death may result from her refusal) and In re Melideo, 88 Misc. 2d 913, 390 N.Y.S.2d 523 (N.Y. Sup. Ct. 1975) (refusal of competent, non-pregnant adult without minor children must be upheld, even though transfusion may be necessary to save her life) with In re President of Georgetown College, Inc., 331 F.2d 1000 (D.C. Cir. 1964) (ordering emergency blood transfusion to save life of Jehovah's Witness with minor child, in spite of her religious objections), cert. denied sub nom. Jones v. President of Georgetown College, Inc., 377 U.S. 978 (1964) and Raleigh Fitkin-Paul Morgan Memorial Hosp. v. Anderson, 42 N.J. 421, 201 A.2d 537 (authorizing blood transfusion for non-consenting pregnant Jehovah's Witness), cert. denied, 377 U.S. 985 (1964); see also J. GoLDSTEIn, A. Freud \& A. Solnit, Before the Best INTEREsts of the Child 95-96 (1979) (discussing unreported decision requiring treatment for newborn, but permitting mother to choose death for herself).

At least one court has held that where a legally incompetent patient's life is not threatened by her religious objections to medical procedures, the court must determine what choice the individual would make if she were competent. See In re Boyd, 403 A.2d 744 (D.C. 1979).

104. Individual decisions to commit suicide or refuse medical treatment are difficult because there is no consensus that a decision to die may be rational. Cf. A. CAMus, The MYTH OF SisYphus 55 (1955) (suicide not justified even if life has no meaning).

105. See Reimann v. Baum, 115 Utah 147, 156-57, 203 P.2d 387, 392 (1949); REstatement of RESTITUTION, supra note $1, \S \S 42(1), 53(2)$ (a) (recovery for mistaken improvements to land limited to increase in value, not cost, if latter is greater); 2 G. PALMER, LAw of Restitution $\$ 10.9$, at 453 (1978).

106. Economic analysis of rescue cases has been largely concerned with determining the efficient (i.e., wealth-maximizing) level of compensation. Diamond \& Mirrlees conclude that giving the total benefit to the rescuer or to the rescuee results in inefficient incentives to avoid losses or to rescue, respectively. Diamond \& Mirrlees, On the Assignment of Liability: The Uniform Case, 6 BrLL J. EcoN. 487, 512 (1975). Landes \& Posner, supra note 1, at 93, argue that judges should award the market price of the rescue, or an approximation of that amount. 
complaining about the size of the recovery. It is still possible, however, that the court will overestimate the subjective value of the benefit to the defendant. ${ }^{107}$ Choosing the minimum recovery to which the plaintiff would have consented minimizes the number of mistakes that can result from such overestimations, thereby maximizing protection of autonomy.

If there is a market for the rescue services, the market price determines the amount of the recovery. ${ }^{108}$ This is easy to determine, although courts have disagreed over the rescuer's right to price discriminate or to charge fees higher than the local average. ${ }^{109}$ Where there is no market for the rescue services, the court must arrive at a reasonable award on equitable principles. ${ }^{110}$ Since this is costly and imprecise, devices such as statutory awards of a percentage of the value of the salved property are useful.111

\section{E. The Failure of Alternative Theories}

Hypothetical contract theory offers a better explanation of the common law of recovery for unsolicited benefits than Posner's wealth-maximization approach. Wealth maximization is an inadequate explanation because the common law denies recovery in many situations in which intervention would create an enormous increase in social wealth. ${ }^{112}$ The explanatory power of the hypothetical contract model thus casts doubt on Posner's general thesis that the common law promotes economic efficiency. ${ }^{113}$

The hypothetical contract theory is also superior to Richard Epstein's

107. The beneficiary may value the benefit more than the amount of the judgment, but less than the sum of the judgment and his litigation costs. Since litigation costs are real costs to the defendant, they should be counted. The plaintiff might be required to pay all costs of litigation, but this would give the beneficiary no incentive to control costs. A better rule is that the plaintiff recovers nothing if the benefit is less than the sum of the cost of the judgment and litigation costs; otherwise, plaintiff recovers and each side pays its own litigation costs.

108. This is the case, for example, when physicians treat unconscious patients. See Cotnam v. Wisdom, 83 Ark. 601, 104 S.W. 164 (1907).

109. Compare id. at $607-08,104$ S.W. at 166-67 (physician may not price discriminate) with Matheson v. Smiley, [1932] 2 D.L.R. 787 (Man. Ct. App.) (price discrimination allowed).

110. The general principles are similar to those used to determine salvage awards in admiralty. See The Blackwall, 77 U.S. (10 Wall.) 1, 14 (1869) (factors include: labor expended by salvors; promptness, skill and energy; value of property employed by salvors, and danger to which such property was exposed; risk incurred by salvors; value of property saved; degree of danger from which property was rescued). The allocatively efficient solution is to pay the rescuer her reservation price-that is, just enough to induce her to carry out the rescue.

111. See, e.g., CAlif. Agric. Cone $\$ 17095$ (West 1968) (estrays); Wade, supra note 1, at 1213 n.162 (collecting statutes).

112. Easy life rescue is the most dramatic case. See Epstein, A Theory of Strict Liability, 2 J. LEgal STUD. 151, 189-91 (1973) (Learned Hand Test would require easy life rescue, since benefit far exceeds cost). The Landes \& Posner paper, see supra note 1, which attempts to reconcile the common law rules with the wealth-maximization principle, is unpersuasive. See 2 G. PALMER, supra note 105, $\S 10.3$ (Supp. 1982). Landes and Posner themselves concede that they fail to show conclusively that the common law rules are consistent with efficiency. Landes \& Posner, supra note 1, at 126.

113. See supra note 50 . 
tort analysis of the unsolicited benefit cases. ${ }^{114}$ Epstein rejects the imposition of tort liability for failure to provide unsolicited benefits, ${ }^{115}$ but agrees that the recipients of those benefits should have to pay for them. ${ }^{116}$ Epstein claims that the primary advantage of his theory of strict liability in tort is its protection of autonomy. ${ }^{117}$ Yet, in order to explain the cases which permit restitution for unsolicited benefits, Epstein introduces ad hoc efficiency considerations that undercut autonomy values. ${ }^{118}$ Thus, Epstein's approach not only is complicated and ad hoc, but it also explicitly trades off autonomy for efficiency. Epstein's approach has been severely criticized on this ground, ${ }^{119}$ and Epstein himself is "uneasy" with the results. ${ }^{120}$

114. Epstein's theory, which imposes tort liability only if the defendant caused the harm in one of four ways, is presented in a series of articles. See Epstein, A Theory of Strict Liability, supra note 112; Epstein, Defenses and Subsequent Pleas in a System of Strict Liability, 3 J. LegaL STuD. 165 (1974); Epstein, Intentional Harns, 4 J. Legal. Stud. 391 (1975).

115. Epstein has argued that a duty to rescue is inconsistent with autonomy values, and cannot be kept from turning into a general duty of beneficence. Epstein, supra note 112, at 189-204.

Many commentators have gone beyond a restitution regime and argued for a duty to rescue, at least when life is at stake and can be saved at no risk and very little cost to the rescuer. See Ames, Law and Morals, 22 HARv. L. Rev. 97, 113 (1908); see also Weinrib, The Case for a Duty to Rescue, 90 Yale L.J. 247, 287-92 (1980) (duty to rescue consistent with Kantian moral philosophy). Such duties are imposed in some civil law countries, see Note, The Failure to Rescue: A Comparative Study, 52 Colum. L. Rev. 631, 635-41 (1952) (discussing duty to rescue in Soviet Union and France), and in Vermont, see VT. Stat. AnN. tit. 12, § 519 (1973), and Minnesota, see MinN. Stat. ANN. $§ 604.05$ (West Supp. 1984).

Rescue duties have seldom been based on hypothetical contract. A recent comment, however, does attempt to base "easy"--that is, riskless and essentially costless-life rescue on a hypothetical contract. See Comment, Bejond Good Samaritans and Moral Monsters: An Individualistic Justification of the General Legal Duty to Rescue, 31 UCLA L. REv. 252, 278 (1983) (Duty to rescue "would be unanimously endorsed by autonomous individuals who structure their social interactions according to general principles.") (italics omitted). This effort, while it suggests the possible range of the hypothetical contract theory, is unconvincing. First, easy rescue is a trivial case. Even low rescue costs create the likelihood that some individuals would not find it worthwhile to enter into a general contract to make easy rescues. Moreover, a duty to rescue deprives rescuers of the utility they might derive from being thought of as altruists. See Landes \& Posner, supra note 1, at 93-94.

116. See Epstein, Causation and Corrective Justice: A Reply to Two Critics, 8 J. Legal Stud. 477, 490-93 (1979).

117. Epstein, supra note 112 , at 203-04.

118. Epstein, supra note 116 , at 490.

119. Posner has criticized this position as internally inconsistent, because Epstein is willing to accept compensation for rescuers, and compensation is also a "forced" transaction. Posner, Epstein's Tort Theory: A Critique, 8 J. Legal Stud. 457, 460-65 (1979); Posner, Strict Liability: A Comment, 2 J. Legal Stud. 205, 218-20 (1973).

120. Epstein has said that he accepts compensation "uneasily," because his concern for autonomy is constrained by efficiency considerations, and because compensation is an administratively cheaper regime than duty to rescue, and a lesser restriction on autonomy. See Epstein, supra note 116, at 490-93. In fact, a compensation regime may be more expensive to administer than is a duty-to-rescue regime. Under a compensation regime, each rescue will result in a costly proceeding. Under a duty-torescue regime, many individuals would simply rescue and go about their business, at no administrative cost. The causation questions under the two regimes are essentially similar. In the compensation cases, the rescuer would have to show that, but for her intervention, the loss would have occurred; in the duty to rescue cases, one who declined to rescue would have to show that the loss would have occurred in spite of her intervention. 


\section{CoNCLUSION}

The theory of hypothetical contract is a logical extension of the law of contract. Hypothetical contract theory explains the common law of restitution for unsolicited benefits better than do competing analyses. In addition to its positive explanatory power, the theory affords greater protection for individual autonomy than do alternative theories of liability.

Critics may object that the theory of hypothetical contract blurs the distinction between liability based on express agreement and liability imposed on other grounds. ${ }^{121}$ Hypothetical contract, one might object, is a long and dangerous step toward the re-absorption of contract law into a general law of obligation, the law of "contorts." not well founded. The theory of hypothetical contract presented here is strictly limited by the requirements of prohibitive transaction costs and Pareto superiority. Moreover, the theory explicitly distinguishes cases decided by extending contractual principles from cases decided on noncontractual principles. Such a clear distinction should retard, not accelerate, the conflation of contract and tort.

-Robert A. Long, Jr.

121. Libertarians, who believe that government is never justified in compelling a redistribution of wealth, might be inclined to take this view. See F. HAYEK, The ConSTITUTION OF LibERTY 93-102 (1960); R. NozICK, supra note 9, at 149-53, 167-74.

122. See G. Gilmore, The Death of Contract 90 (1974); P. Atiyah, The Rise and Fal. of Freedom of ConTRAct 717-79 (1979) (move away from executory model of exchange). Posner also argues for breaking down the walls of the doctrinal compartments. Posner, Epstein's Tort Theory, supra note 119, at 464 (Tort, contract, and restitution "reflect a common concern with facilitating the operation of free markets given positive transaction costs."). 